\title{
Synthetic profiles of polypeptides of human oocytes and normal and abnormal preimplantation embryos
}

\author{
G. Capmany and V. N. Bolton* \\ Assisted Conception Unit, Department of Obstetrics and Gynaecology, King's College School of Medicine and Dentistry, \\ Bessemer Road, London SE5 8RX, UK
}

\begin{abstract}
There is considerable variation in the rate of development in vitro of individual preimplantation human embryos. The relationship between the rate of development and patterns of polypeptide synthesis in individual embryos was examined using SDS-PAGE and autoradiography. After incubation in ${ }^{35}$ S]methionine, 19 polypeptide bands were identified that change between fertilization and the morula stage. Although changes in two of the bands occurred in embryos that were developing normally and in ageing oocytes, and are thus independent of fertilization, the changes identified in the remaining 17 bands occurred only after fertilization. In embryos that were developing abnormally, as assessed by delayed cleavage, cleavage arrest or extensive fragmentation, the alteration in polypeptide synthetic profiles increased with increasing abnormality.
\end{abstract}

\section{Introduction}

Human embryos derived by in vitro fertilization (IVF) differ both in the rate at which they develop in vitro and in morphology (Plachot et al., 1988; Bolton et al., 1989). It has been estimated that between 16\% (Saito et al., 1994) and $46 \%$ (Plachot et al., 1989) of embryos show some degree of extracellular fragmentation, and that approximately $30-37 \%$ of embryos undergo delayed cleavage (Hardy et al., 1989; Plachot et al., 1989). The rate of blastocyst formation in vitro, which varies depending on the culture system (co-culture, sequential media), the time of evaluation and whether the studies involved cavitating, expanding or fully expanded blastocysts, is about 50\% (Muggleton-Harris et al., 1995; Wiemer et al., 1995; Ben-Chetrit et al., 1996; Quinn and Margelit, 1996; Turner and Lenton, 1996; Desai et al., 1997; Alves da Motta et al., 1998; Gardner and Lane, 1998; Gardner et al., 1998; Jones et al., 1998a,b; Martin et al., 1998; Shoukir et al., 1998a).

Several reasons have been suggested for the apparently low survival rate of human embryos developing in vitro. These include chromosomal abnormalities (Munné et al., 1994, 1995; Almeida and Bolton, 1996); multinucleation of blastomeres (Levy et al., 1998); deficiencies in the culture medium (Artley and Braude, 1993); exposure to increased concentrations of oxygen free radicals during culture in vitro (Johnson and Nasr-Esfahani, 1994); paternal (Sathananthan, 1994; Menezo et al., 1995; Shoukir et al., 1998b), cytoplasmic (Braude et al., 1990; Van Blerkom et al., 1995) and genetic factors inherent to each embryo (Warner et al., 1998); and epigenetic causes (Van Blerkom, 1998). Furthermore, major activation of the embryonic genome, which occurs between the four- and eight-cell stages in humans (Braude et al., 1988),

\footnotetext{
*Correspondence address: Assisted Conception Unit, Ruskin Wing, 7th Floor, King's College Hospital, Denmark Hill, London SE5 8RX, UK. Received 27 October 1998.
}

coincides with the highest incidence of developmental arrest. This is also the case in other mammalian embryos developing in vitro (mouse: Flach et al., 1982; pig: Davis, 1985; sheep: Crosby et al., 1988; cow: Frei et al., 1989; goat: Sakkas et al., 1989; hamster: Seshagiri et al., 1990; reviewed by Telford et al., 1990; Watson et al., 1993), indicating that developmental arrest of embryos may be associated with failure to activate the embryonic genome (Braude et al., 1988, 1990). It is likely that embryos with different developmental potential express different patterns of protein synthesis, either inherently or as a result of environmental insult. This possibility was investigated in only one study in which the protein synthetic profiles of preimplantation human embryos that had undergone developmental arrest between the pronucleate and eight-cell stages were examined (Artley et al., 1992). Activation of the embryonic genome had occurred in only $50 \%$ of the embryos (Artley et al., 1992). To date, there have been no reports of analysis of embryos that either cleave slowly or show extensive fragmentation.

In the present study on human embryos, protein synthetic patterns were determined in preimplantation embryos that were developing normally (Braude et al., 1990), ageing unfertilized oocytes, and embryos showing slow cleavage, developmental arrest, extensive fragmentation or a combination of these. The aim was to investigate the relationship between normal and abnormal development and specific patterns of polypeptide synthesis.

\section{Materials and Methods}

\section{Source of oocytes and embryos}

Human oocytes and embryos were donated by patients undergoing therapeutic IVF, with their informed consent. This work was approved by King's College Hospital Ethics 
Committee, and licensed by the Human Fertilisation and Embryology Authority (HFEA), license number R0061. Ovarian stimulation, oocyte collection and IVF were carried out as described by Bolton et al. (1989) and Waterstone and Parsons (1992), with the exception that the culture medium (Earle's balanced salt solution; EBSS) was supplemented with $0.001 \%(\mathrm{v} / \mathrm{v})$ synthetic serum replacement (SSR; Imperial Laboratories) and $1 \%(\mathrm{w} / \mathrm{v})$ human serum albumin.

Oocytes were examined for the presence of pronuclei at 18-20 $\mathrm{h}$ after insemination. Only those embryos that developed two pronuclei were included in the study. Embryos resulting from zygotes with one or three pronuclei were excluded. Unfertilized oocytes used for this study came from cohorts in which none of the oocytes developed pronuclei after insemination with suboptimal spermatozoa to ensure analysis of an unselected population of oocytes (WHO Guidelines; Capmany and Bolton, 1993). (Intracytoplasmic sperm injection (ICSI) was unavailable at the time of the study, and patients with male factor infertility were offered at least one treatment cycle; if all of the oocytes failed to fertilize, patients were counselled towards other options.)

\section{Scoring}

Embryos were considered to be developing normally if they had developed two pronuclei at $20 \mathrm{~h}$ after insemination, and cleaved to the four-, eight-, and 16-cell stages by 45,69 and $93 \mathrm{~h}$ after insemination, respectively (Braude et al., 1990). Embryos were scored for morphology according to the degree of extracellular fragmentation (Fig. 1). Embryos with regular spherical blastomeres or $<10 \%$ fragmentation were considered to have good morphology; embryos with irregular blastomeres or $>10 \%$ fragmentation were classified as having poor morphology (modified from Bolton et al., 1989). Cleavage was considered to be delayed if two pronuclei had developed at $20 \mathrm{~h}$ after insemination and cleavage had occurred, but embryos had failed to cleave to the four-, eight- and 16-cell stages by 45,69 and $93 \mathrm{~h}$ after insemination, respectively. Embryos were considered arrested if they failed to cleave for at least $24 \mathrm{~h}$.

\section{Labelling with $\left[{ }^{35}\right.$ S $]$ methionine}

Oocytes and embryos at 21, 45, 69 or $93 \mathrm{~h}$ after insemination were incubated for $3 \mathrm{~h}$ in EBSS containing $0.75 \mathrm{mCi}$ $\left[{ }^{35}\right.$ S] methionine $\mathrm{ml}^{-1}$ (specific activity $>1000 \mathrm{Ci} \mathrm{mmol}^{-1}$; Amersham International, Amersham). After incubation, they were rinsed four times in $1 \mathrm{ml}$ drops of PBS (Sigma, Poole) and the zona pellucida was removed using acid Tyrode's solution ( $\mathrm{pH} 2.5$ ). After a further rinse in PBS, zona-free oocytes and embryos were stored individually in $2-3 \mu \mathrm{l}$ PBS at $-20^{\circ} \mathrm{C}$ for up to 2 weeks before electrophoresis. A small number of embryos that cleaved during the $3 \mathrm{~h}$ incubation in $\left[{ }^{35} \mathrm{~S}\right]$ methionine were excluded from the study.

\section{Polyacrylamide gel electrophoresis}

Individual oocytes and embryos were analysed using one-dimensional SDS-PAGE. Immediately before SDS-PAGE,
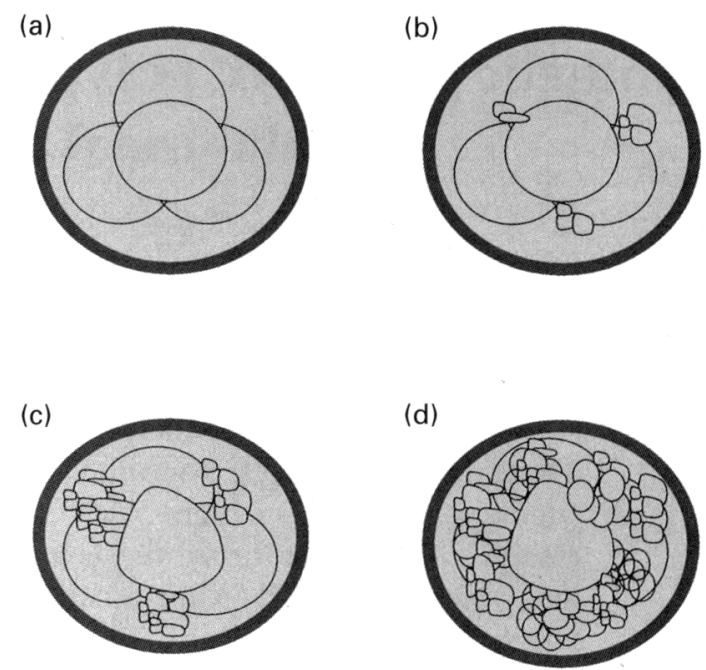

Fig. 1. Diagrammatic representation of grading system for human embryos using a four-cell embryo. (a,b) Embryos with regular spherical blastomeres or $<10 \%$ fragmentation were considered to have good morphology; (c,d) embryos with irregular blastomeres or $>10 \%$ fragmentation were considered to have poor morphology (modified from Bolton et al., 1989).

$10 \mu \mathrm{l}$ sample buffer containing $20 \mathrm{mmol}$ dithiothreitol (DTT) $1^{-1}$ was added to each sample (Laemmli, 1970). After loading one oocyte or one embryo per lane, mini-gels $(8.5 \%(\mathrm{v} / \mathrm{v})$ polyacrylamide) were subjected to electrophoresis at $200 \mathrm{~V}$ and fixed for $40 \mathrm{~min}$ in a mixture of methanol, acetic acid and water (10:2:7 by volume) containing $5 \%(\mathrm{v} / \mathrm{v})$ fixative enhancer (Bio-Rad, Hemel Hempstead). The gels were stained immediately with Silver Stain Plus (Bio-Rad). After photography, the gels were vacuum dried and exposed to Fuji RX X-ray film for $3-6$ weeks at $-70^{\circ} \mathrm{C}$.

\section{Analysis of data}

The autoradiograms were assessed visually and a semiquantitative estimate of the intensity of individual polypeptide bands was made in relation to the overall intensity of the gel. The analysis was blind and was always performed by the same observer to avoid any possible biasing and differences in the criteria used for scoring the bands. Since $8.5 \%$ gels do not give good resolution below $26 \mathrm{kDa}$ and over $90 \mathrm{kDa}$, only those bands between 30 and $90 \mathrm{kDa}$ were analysed for the study.

In all but two of the bands analysed, a five grade scale of relative intensity was used: absent, very weak, weak, medium and strong. When discrete bands could not be identified clearly, bands were classified as non-analysable (NA), and the data were not included in the analysis.

\section{Statistical analysis}

Statistical analysis was performed using Fisher's exact test. The level of significance was $P=0.05$. 
Table 1. Number, cleavage rate and morphology of human embryos that yielded bands after SDS-PAGE and silver staining

\begin{tabular}{lcccc} 
& & \multicolumn{3}{c}{ Cleavage rate } \\
\cline { 3 - 5 } Bands after autoradiography & Embryo morphology & Normal & Slow & Arrested \\
\hline \multirow{2}{*}{ Analysable $(n=125)$} & Good & 14 & 35 & 26 \\
Not analysable $(n=16)$ & Poor & 7 & 22 & 21 \\
& Good & 1 & 1 & $5^{*}$ \\
\hline
\end{tabular}

${ }^{*}$ Four embryos had arrested at the one-cell stage.

tAll embryos had two or more cells.

\section{Results}

A total of 141 embryos from 60 women (mean of three embryos per patient, range 1-6) and 59 oocytes from 15 women (mean of four oocytes per patient, range 2-5) were processed by SDS-PAGE, all of which yielded analysable bands after silver staining. The only differences identified in oocytes and embryos were among a group of polypeptides of $69 \mathrm{kDa}$; these were described by Capmany and Bolton (1993) and were not associated with chronological age, rate of development or morphology (data not shown). The morphology and developmental rate of embryos that yielded analysable bands after silver staining are summarized (Table 1 ).

Seven oocytes and 16 embryos failed to incorporate [35S]methionine. Of the seven oocytes, one was labelled at $69 \mathrm{~h}$ after insemination, and two each at 21, 45 and $93 \mathrm{~h}$ after insemination. Of the 16 embryos that failed to incorporate [ ${ }^{35} \mathrm{~S}$ ]methionine, in 15 development was either slow or arrested, and nine showed poor morphology (Table 1). When only the morphology of the embryos was taken into account, there was a statistically significant difference between the percentage of embryos with good or poor morphology that failed to incorporate $\left[{ }^{35} S\right]$ methionine $(P=0.03)$. In addition, when only cleavage-stage arrested embryos were considered, there was a statistically significant difference between the percentage of embryos with good or poor morphology that failed to incorporate $\left[{ }^{35} S\right]$ methionine $(P=0.05)$.

SDS-PAGE revealed 19 bands that showed differences between oocytes and embryos with chronological age or stage of development. There were a number of differences in the polypeptide synthetic profiles of embryos that had good morphology and were developing normally compared with ageing oocytes, or embryos with good or poor morphology that were developing slowly or had arrested. These differences were not always consistent within a subgroup of oocytes or embryos. However, certain patterns of polypeptide synthesis were more common in one subgroup than another. These changes are summarized below.

\section{Polypeptide synthesis and normal development}

The protein synthetic patterns of 25 embryos with good morphology that were developing normally were analysed (pronucleate: $n=11$; four-cell: $n=5$; eight-cell: $n=4$; 16-cell: $n=3$; morulae: $n=2$ ). The results obtained are summarized
(Table 2). There were changes in 19 bands as development progressed (Fig. 2).

Band 3 resolved differently during fertilization and in normally developing embryos at different stages. In unfertilized oocytes at $21 \mathrm{~h}$ after insemination, two bands of low to medium intensity were observed (Fig. 2, lane A). In pronucleate stage embryos of the same chronological age, the band resolved as a single very intense band, consistent with increased synthesis of either a single band or of the same two bands observed in unfertilized oocytes $(21 \mathrm{~h}$ after insemination; Fig. 2, lane B). At the four-cell stage, synthesis decreased and the band resolved as two bands of equal intensity ( $45 \mathrm{~h}$ after insemination; Fig. 2, lane $\mathrm{C}$ ), and by the 16-cell stage (morula) only the upper band of the duplex could be detected ( $93 \mathrm{~h}$ after insemination; Fig. 2, lanes D,E).

\section{Polypeptide synthesis in ageing oocytes}

Comparison of the polypeptide synthetic profile of human oocytes that had aged in vitro $(45,69$ and $93 \mathrm{~h}$ after insemination) with that of oocytes at $21 \mathrm{~h}$ after insemination revealed changes in two polypeptide bands (bands 3 and 11). A similar pattern of synthesis of band 11 was observed in both ageing oocytes and normal embryos of the same chronological age, whereas there was a slight difference in the pattern of synthesis of band 3 between ageing oocytes and normal embryos (Fig. 3).

\section{Polypeptide synthesis and slow development}

The protein synthetic patterns of 35 embryos with good morphology that were developing slowly were compared with those of embryos with good morphology that were developing normally. Differences were observed in the pattern of synthesis of 11 polypeptide bands. These differences were classified as follows: (i) changes that proceeded with time (time-dependent; band 10); (ii) changes that depended on the number of cleavage divisions (cleavage-dependent; bands 1,5,11 and 18); and (iii) changes that did not appear to be associated with either time or cleavage (bands 2, 3, 9, 12, 15 and 17) (Fig. 4).

\section{Polypeptide synthesis and cleavage arrest}

The protein synthetic patterns of 29 pronucleate stage embryos that failed to cleave were analysed at $45 \mathrm{~h}(n=16)$ 
Table 2. Semi-quantitative analysis of changes in the pattern of synthesis of 19 bands during the development of normal preimplantation human embryos

\begin{tabular}{|c|c|c|c|c|c|c|}
\hline Band & $\begin{array}{l}\text { Molecular } \\
\text { mass (kDa) }\end{array}$ & $\begin{array}{l}\text { No pronuclei } \\
\text { (21 h after } \\
\text { insemination) }\end{array}$ & $\begin{array}{l}\text { Two pronuclei } \\
(21 \mathrm{~h} \text { after } \\
\text { insemination })\end{array}$ & $\begin{array}{c}\text { Four-cell } \\
\text { (45 h after } \\
\text { insemination) }\end{array}$ & $\begin{array}{c}\text { Eight-cell } \\
\text { (69 h after } \\
\text { insemination) }\end{array}$ & $\begin{array}{c}\text { Morula } \\
\text { (93 h after } \\
\text { insemination) }\end{array}$ \\
\hline 1 & 87 & - & - & - & + & + \\
\hline 2 & 78 & ++ & - & + & ++ & ++ \\
\hline $3^{*}$ & 71 & One strong band & One strong band & Two bands & Transition & Upper band \\
\hline 4 & 67 & + & + & ++ & ++ & ++ \\
\hline 5 & 64 & ++ & ++ & ++ & +++ & +++ \\
\hline 6 & 61 & ++ & ++ & + & + & + \\
\hline 7 & 58 & ++ & ++ & + & ++ & $++t$ \\
\hline 8 & 55 & - & + & ++ & ++ & ++ \\
\hline 9 & 54 & +++ & +++ & ++ & - & + \\
\hline 10 & 53 & - & + & + & ++ & ++ \\
\hline 11 & 52 & - & - & + & + & + \\
\hline 12 & 49 & $+t$ & $+t$ & + & ++ & +++ \\
\hline 13 & 47 & ++ & ++ & + & - & - \\
\hline 14 & 45 & ++ & ++ & t+ & +++ & $++t$ \\
\hline 15 & 44 & +++ & $++t$ & $+t$ & ++ & ++ \\
\hline 16 & 41 & ++ & +++ & ++ & $+t$ & ++ \\
\hline 17 & 39 & ++ & + & + & ++ & ++ \\
\hline 18 & 37 & ++ & + & + & ++ & $+t$ \\
\hline 19 & 35 & $++t$ & +++ & $+t$ & $+t$ & ++ \\
\hline
\end{tabular}

- , not detectable; + , weak; ++, medium; +++, strong.

*The pattern of synthesis of band 3 changed during development from one very strong band (no and two pronuclei stages), to two bands of equivalent intensity (four-cell stage), to weaker synthesis of the lower band (eight-cell stage), to synthesis of the upper band only (16-cell stage).

and $69 \mathrm{~h}(n=13)$ after insemination and compared with those of normally developing embryos with good morphology (Fig. 5).

Some of the changes identified in polypeptides synthesized by embryos with good morphology that had arrested during cleavage are shown (Fig. 5). There were similar changes with time in the pattern of synthesis of five polypeptide bands $(1,3,9,10$ and 18) in both normal and cleavage-stage arrested embryos. The changes in the patterns of synthesis of bands 2, 5, 8, 12 and 15 did not appear to be associated wholly with either cleavage or chronological age.

\section{Polypeptide synthesis and embryo morphology}

The protein synthetic profiles of 125 cleavage stage embryos were analysed, of which 75 had good morphology and 50 poor morphology (Table 1). The differences in the patterns of polypeptide synthesis in equivalent stage embryos with good and poor morphology are shown (Fig. 6).

Changes in the synthesis of bands 5, 12 and 17 were identified in embryos with poor morphology that were cleaving at the normal rate. In embryos with poor morphology that were developing slowly, differences were identified in the pattern of synthesis of five polypeptide bands (2, 3, 9, 11 and 17). However, there were fewer common trends among embryos with poor morphology as the degree of developmental anomaly increased, such that hardly any trends could be identified in arrested embryos with poor morphology. The most marked changes were in the patterns of bands $8,9,11$ and 15 .

\section{Discussion}

Use of SDS-PAGE and autoradiography identified 19 polypeptide bands that change between fertilization and the morula stage in human oocytes and embryos. Most of the changes occur between the pronucleate and four-cell stages, when there appears to be an overall decrease in polypeptide synthesis, and between the four- and eight-cell stages, coinciding with major activation of the embryonic genome (Braude et al., 1989).

In the preimplantation mouse embryo, changes in the patterns of protein synthesis before activation of the embryonic genome appear to be regulated in one of three ways (Howlett and Bolton, 1985): although most of the changes are dependent on fertilization, others are either accelerated by fertilization or are independent of this process. In the present study, comparison of protein synthetic profiles of normally developing human embryos and ageing oocytes indicated that similar regulation operates in human embryos. Thus, 17 of the 19 polypeptide bands described in this study showed changes that were dependent on fertilization, since they did not occur in ageing oocytes. Of the remaining two bands, one showed changes that were independent of fertilization (band 11) and one (band 3) showed changes that were triggered independently of fertilization, but were only completed in developing embryos.

The changes in polypeptide synthesis at fertilization were described in a study in which the patterns of synthesis of unfertilized oocytes at $21 \mathrm{~h}$ after insemination were compared with those of tripronuclear embryos of the same Downloaded from Bioscientifica.com at 04/26/2023. 11:01:17AM 


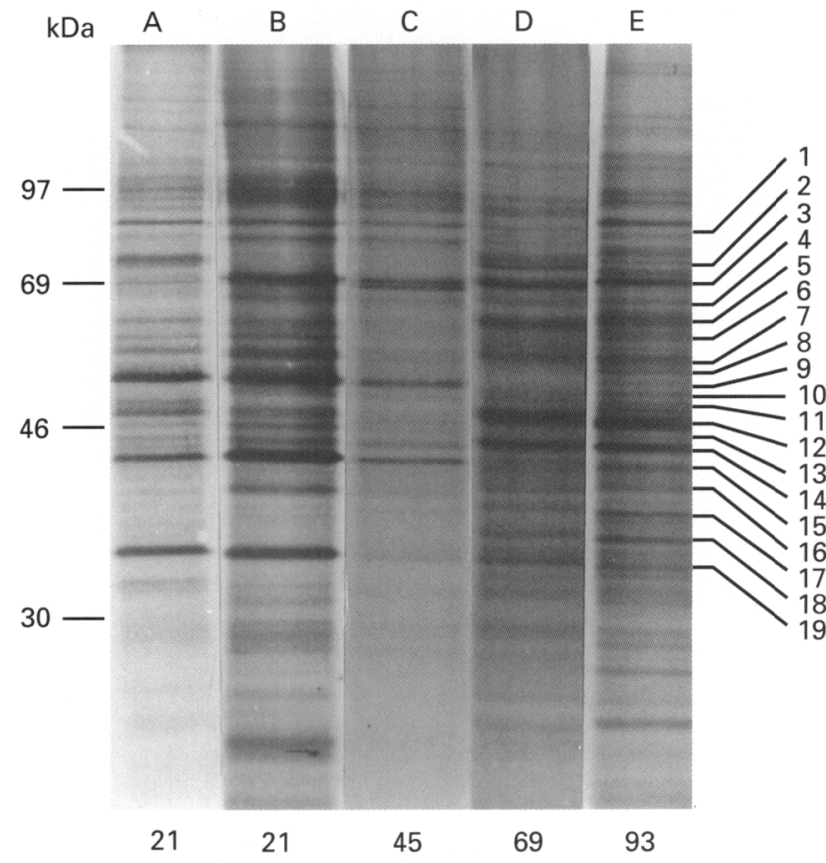

Time after insemination (h)

Fig. 2. Autoradiograph of SDS-PAGE separated polypeptides synthesized by an ageing human oocyte (A) and by human embryos with good morphology that were developing normally (B-E) during $3 \mathrm{~h}$ incubation in [ $\left.{ }^{35} \mathrm{~S}\right]$ methionine. $\mathrm{A}$, unfertilized oocyte at $21 \mathrm{~h}$ after insemination; $\mathrm{B}$, pronucleate stage embryo at $21 \mathrm{~h}$ after insemination; $\mathrm{C}$, four-cell embryo at $45 \mathrm{~h}$ after insemination; $\mathrm{D}$, eight-cell embryo at $69 \mathrm{~h}$ after insemination; E, morula at $93 \mathrm{~h}$ after insemination. Approximate molecular masses (kDa) are shown on the left. Numbers on the right indicate bands that changed between fertilization and the morula stage.

age (Dionne et al., 1989). Changes were identified in seven polypeptide bands; two of these ( 26 and $28 \mathrm{kDa}$ ) had molecular masses that were too small for consistent analysis in the mini-gel system used in the present study, and three bands $(54,36.5$ and $35.3 \mathrm{kDa}$ ) were not identified in the present study. The remaining two bands ( 42.5 and $41.2 \mathrm{kDa}$ ) may correspond to bands 15 and 16 in the present study, although the patterns of synthesis differ markedly between the reports. The differences between the two studies may be the result of the longer incubation in $\left[{ }^{35} \mathrm{~S}\right]$ methionine $(5 \mathrm{~h})$ in the study of Dionne et al. (1989), or the analysis of abnormal embryos, since no tripronucleate embryos were included in the present study.

There are four reports of the analysis of the polypeptide synthetic profile of ageing unfertilized human oocytes up to $100 \mathrm{~h}$ after insemination (Gifford et al., 1987; Braude et al., 1988; Schultz et al., 1988; Artley et al., 1992). Only Gifford et al. (1987) identified any differences between fresh (44-46 h after hCG) and aged unfertilized oocytes (82-86 h after hCG; $42-46 \mathrm{~h}$ after insemination), although these differences were not described in detail. In the present study, age-related changes in the pattern of synthesis of two polypeptide bands were identified.

In mice, incorporation of $\left[{ }^{35} \mathrm{~S}\right]$ methionine into ageing oocytes cultured for $48 \mathrm{~h}$ decreased by $92 \%$ compared with

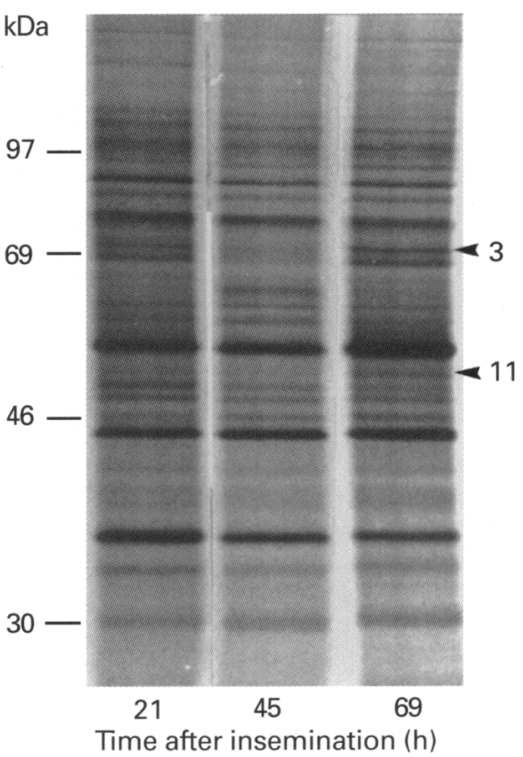

Fig. 3. Autoradiograph of SDS-PAGE separated polypeptides synthesized by individual ageing unfertilized human oocytes processed at 21-69 h after insemination. Arrowheads show bands 3 and 11. Molecular mass markers (kDa) are shown on the left.

fresh oocytes (Petzoldt et al., 1980). This decrease was due to lack of transcription from the embryonic genome, which commences in developing embryos of the same chronological age (Flach et al., 1982). Although major activation of the human embryonic genome occurs between the four- and eight-cell stages ( 69 and $93 \mathrm{~h}$ after insemination; Braude $e t$ al., 1988 ), no difference in overall incorporation of $\left[{ }^{35} \mathrm{~S}\right]$ methionine was apparent from the semi-quantitative analysis of oocytes aged in culture up to $93 \mathrm{~h}$ after insemination, indicating that human maternal mRNA is stable until at least $93 \mathrm{~h}$ after insemination (136 h after hCG).

Braude et al. (1988) and Artley et al. (1992) described the polypeptide synthetic patterns of human unfertilized oocytes, and normal and arrested preimplantation embryos. However, to date, there have been no reports describing the polypeptide synthetic patterns of human embryos that are developing slowly or that have poor morphology. In the studies of Braude et al. (1988) and Artley et al. (1992), changes in the pattern of synthesis of eight polypeptide bands during preimplantation development were described, seven of which appear to correspond to bands identified in the present study. A comparison of the changes in these bands in the present study and in the studies of Braude et al. (1988) and Artley et al. (1992) is shown (Table 3). It is likely that minor discrepancies among the studies reflect qualitative differences in the embryos. Firstly, the morphology of the embryos is only described in the present study. Secondly, the criteria for normal embryos are more stringent in the present study compared with the earlier studies; no embryos at intermediate cleavage stages (three-, five-, six-, or seven-cell stages) were included in the normal population, and embryos were processed at specific times each day to restrict the heterogeneity in each group to a minimum. In contrast, in the 


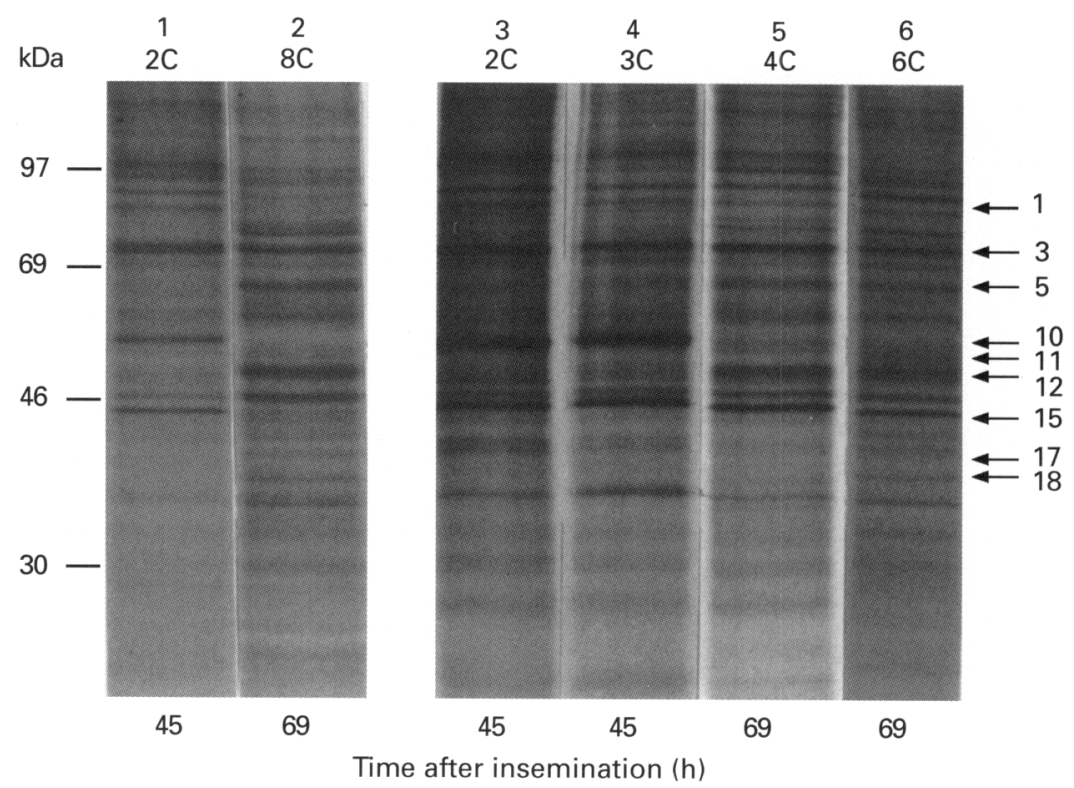

Fig. 4. Autoradiograph of SDS-PAGE separated polypeptides synthesized by individual human embryos that were developing normally (lanes 1 and 2) or developing slowly (lanes 3-6). Arrows show some of the bands that had different patterns in normally developing embryos and embryos that were cleaving slowly. $2 C$, two-cell embryo; $3 \mathrm{C}$, three-cell embryo; $4 \mathrm{C}$, four-cell embryo; $6 \mathrm{C}$, six-cell embryo; $8 \mathrm{C}$, eight-cell embryo. Molecular mass markers ( $\mathrm{kDa}$ ) are shown on the left.

study by Artley et al. (1992), the control population of embryos, which consisted of 14 non-arrested embryos, included two groups of embryos of the same chronological age but with a different number of cells: one three-, one fourand one five-cell embryo of the same chronological age, and an eight-cell embryo, a morula and a blastocyst of the same age. Alternatively, the discrepancies among the studies may be the result of the different electrophoretic systems used, which can have different resolution capacities.

This is the first report of the polypeptide synthetic patterns of human embryos that develop more slowly than normal. Comparison of the polypeptides synthesized by normal and by slowly developing embryos indicates that some changes in synthesis occur according to the chronological age of the embryo, irrespective of cleavage, and are presumably regulated by mechanisms associated with the period after a triggering event, such as the LH surge (or hCG injection) or fertilization. Other changes appear to be dependent upon a certain number of cell cycles and are presumably regulated by mechanisms associated with cytokinesis. A third group of changes appear to be intermediate, in that they proceed with time, but at a reduced rate in the absence of a certain number of cleavage divisions. Although this may be the result of asynchrony among blastomeres, it is possible that synthesis of these polypeptides is regulated by mechanisms associated with both cytokinesis and time. The results indicate that changes in a number of bands that are time- or cleavage-dependent in slowly developing embryos depend on both mechanisms in arrested embryos. However, since the pattern of polypeptide synthesis becomes more altered as development progresses in abnormal embryos, it is possible that this only reflects a gross alteration in the pattern of polypeptide synthesis.

The polypeptide synthetic profiles of arrested embryos and embryos with poor morphology display a greater number of differences from normally developing embryos than embryos that are developing slowly. This finding indicates that as developmental abnormality increases, so does the variation in the pattern of polypeptide synthesis. This contention is confirmed by the observation that a significantly larger number of embryos with poor morphology failed to incorporate $\left[{ }^{35} S\right]$ methionine than those with good morphology.

A number of the polypeptide bands (for example 9, 10, 15 and 18) that showed differential expression in abnormal embryos also showed increased synthesis compared with normal embryos. Although upregulation of protein synthesis in embryos that are not developing normally might seem contradictory, it may be the result of the downregulation of modulators of protein synthesis, such as promoters or enhancers.

Use of the transcriptional inhibitor $\alpha$-amanitin showed that from the four- to the eight-cell stages, synthesis of bands B, D, E and G (Artley et al., 1992) was regulated at the transcriptional level of the embryonic genome. When normal embryos had cleaved to at least the eight-cell stage, $50 \%$ of arrested embryos ( 25 of 48 cleavage stage embryos and two of six pronucleate stage embryos) had undergone gene activation (Artley et al., 1992). Bands B, D, E and G from the study of Artley et al. (1992) appear to correspond to bands 15, 
Table 3. Comparison of the pattern of synthesis of the seven polypeptide bands described in the present study and in the studies of Braude et al. (1988) and Artley et al. (1992)

\begin{tabular}{|c|c|c|c|}
\hline \multicolumn{3}{|c|}{ Band (approximate molecular mass in $\mathrm{kDa}$ ): } & \multirow{2}{*}{$\begin{array}{l}\text { Change in pattern of synthesis } \\
\text { during development }\end{array}$} \\
\hline (1) Braude et al., 1988 & (2) Artley et al., 1992 & (3) Present study & \\
\hline $\mathrm{A}(36 \mathrm{kDa})$ & $\mathrm{A}(37 \mathrm{kDa})$ & $\begin{array}{l}19(35 \mathrm{kDa}) \\
\text { (2) } d \text {, two-cell } \\
\text { (3) } \downarrow \text {, four-cell }\end{array}$ & (1) $\downarrow$, four-cell; d, eight-cell \\
\hline $\mathrm{B}(40 \mathrm{kDa})$ & $\mathrm{B}(41 \mathrm{kDa})$ & $\begin{array}{l}15(44 \mathrm{kDa}) \\
\text { (2) } \downarrow \text {, after eight-cell } \\
\text { (3) } \downarrow \text {, four-cell }\end{array}$ & (1) $\downarrow$, after eight-cell \\
\hline $\mathrm{C}(45 \mathrm{kDa})$ & $\mathrm{D}(46 \mathrm{kDa})$ & $\begin{array}{l}12(49 \mathrm{kDa}) \\
\text { (2) a, four-cell } \\
\text { (3) } \downarrow \text {, four-cell; } \uparrow, \text { eigh }\end{array}$ & $\begin{array}{l}\text { (1) a, eight-cell } \\
\text { t-cell }\end{array}$ \\
\hline $\mathrm{D}(50 \mathrm{kDa})$ & - & $\begin{array}{l}9(54 \mathrm{kDa}) \\
\text { (2) Not identified } \\
\text { (3) } \downarrow \text {, four-cell }\end{array}$ & (1) $\downarrow$, four-cell \\
\hline $\mathrm{E}(75 \mathrm{kDa})$ & $\mathrm{G}(74 \mathrm{kDa})$ & $\begin{array}{l}2(78 \mathrm{kDa}) \\
\text { (2) } a, \text { four-cell } \\
\text { (3) a, four-cell }\end{array}$ & (1) a, eight-cell \\
\hline- & $\mathrm{C}(44 \mathrm{kDa})$ & $\begin{array}{l}14(45 \mathrm{kDa}) \\
\text { (2) } \uparrow, \text { two-cell onwarc } \\
\text { (3) } \downarrow \text {, four-cell; } \uparrow \text {, eigh }\end{array}$ & $\begin{array}{l}\text { (1) Not identified } \\
\text { t-cell }\end{array}$ \\
\hline- & $\mathrm{E}(51 \mathrm{kDa})$ & $\begin{array}{l}7 \text { (58 kDa) } \\
\text { (2) a, four-cell } \\
\text { (3) } \downarrow, \text { four-cell; } \uparrow, \text { eigh }\end{array}$ & $\begin{array}{l}\text { (1) Not identified } \\
\text { t-cell }\end{array}$ \\
\hline
\end{tabular}

$\mathrm{a}=$ synthesis first detected; $\mathrm{d}=$ synthesis undetectable; $\uparrow=$ increase in intensity; $\downarrow$ = decrease in intensity.

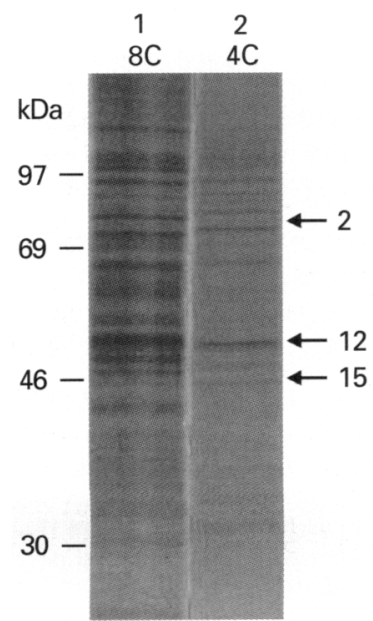

69

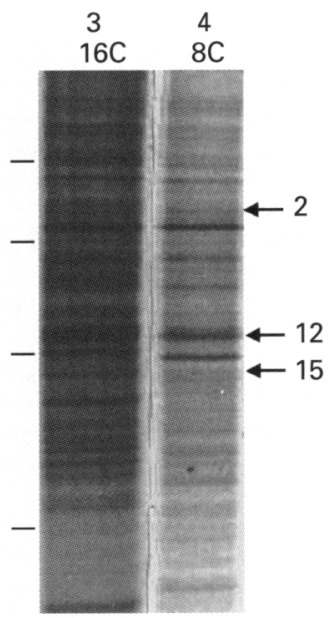

9393

Time after insemination (h)

Fig. 5. Autoradiograph of SDS-PAGE separated polypeptides synthesized by individual human embryos that were developing normally (lanes 1 and 3) or were arrested (lanes 2 and 4). Arrows show three of the bands that had different patterns in normally developing and arrested embryos. $4 \mathrm{C}$, four-cell embryo; $8 \mathrm{C}$, eightcell embryo; 16C, 16-cell embryo. Molecular mass markers (kDa) are shown on the left.

12,7 and 2 from the present study. If this is correct, the results of the present study indicate that, contrary to the findings of Artley et al. (1992), all 47 embryos arrested at the twoto eight-cell stages that were labelled at 69 or $93 \mathrm{~h}$ after insemination had activated transcription; normally developing embryos would have reached the eight-cell or morula
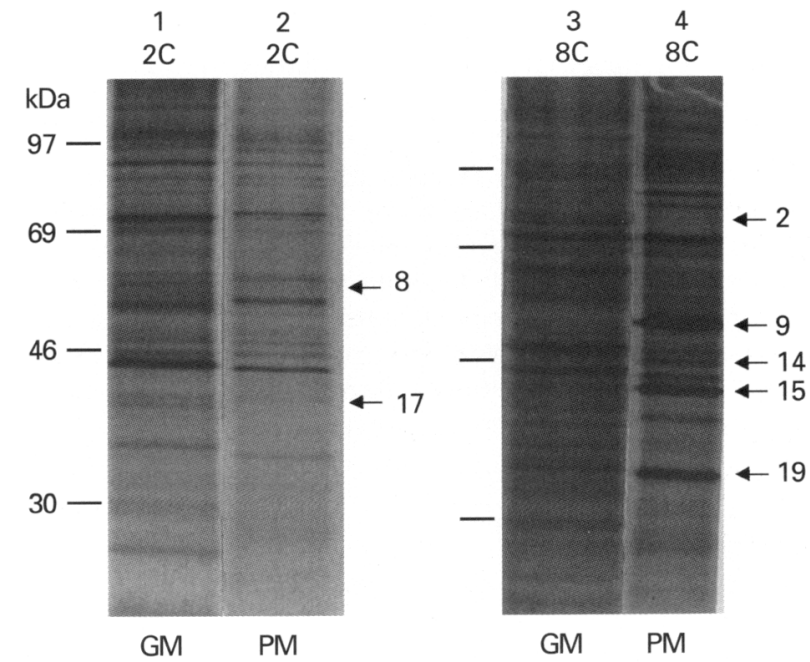

Fig. 6. Autoradiograph of SDS-PAGE separated polypeptides synthesized by individual human embryos at different cleavage stages, showing some of the differences (arrows) identified between embryos of the same chronological age and cleavage stage, but with good morphology (GM; lanes 1 and 3) or poor morphology (PM; lanes 2 and 4). 2C, two-cell embryo; 8C, eight-cell embryo. Molecular mass markers $(\mathrm{kDa})$ are shown on the left.

stages, respectively. However, $46 \%(6 / 13)$ of embryos that had arrested at the one-cell stage and were cultured until $69 \mathrm{~h}$ after insemination failed to show signs of activation of the embryonic genome. The reason for these discrepancies is not clear. One possibility is that the bands described in the present study do not correspond to those identified by Artley 
et al. (1992), although this is unlikely. From the present results, it appears that provided at least one cleavage division has taken place, activation of the embryonic genome proceeds according to an inherent temporal programme, irrespective of subsequent cleavage or the extent of fragmentation of the embryo. Alternatively, failure to activate the embryonic genome could be related to failure to undergo the first round of DNA replication. The use of an inhibitor of DNA synthesis has demonstrated that major activation of the embryonic genome in the mouse requires the first, but not the second, round of DNA replication (Bolton et al., 1984; Howlett, 1986). Unfortunately, in the present study, it was not possible to determine whether embryos that had failed to undergo cytokinesis had undergone DNA replication.

Whether the differences in polypeptide synthesis observed in the present study are the result or the cause of the developmental anomalies analysed remains unclear. It is of interest that there is some variation in the polypeptide patterns of normal embryos. Although this may be explained by asynchrony among blastomeres, it is possible that development is already compromised in some embryos that appear to be normal. In spite of these individual differences, the variation among polypeptide synthetic profiles of embryos that appear to be developing normally is relatively small, which allows identification of trends within different groups of oocytes and embryos. Future studies should involve direct analysis of the RNA present in human embryos at different stages of development with the aim of identifying genes that show differential expression throughout early development.

The authors wish to thank the staff of the Assisted Conception Unit at King's College Hospital for their help in supplying the oocytes and embryos used in this work, the members of the Department of Medical Photography at King's College School of Medicine and of the Servei de Microscopia Electronica of the Universitat Autònoma de Barcelona for their help with the figures, and Dr Josep Santalo for critically reviewing the final manuscript. G. Capmany was supported by a grant from the EC Science Programme.

\section{References}

Almeida PA and Bolton VN (1996) The relationship between chromosomal abnormality in the human preimplantation embryo and development in vitro. Reproduction Fertility and Development 8 235-241

Alves da Motta EL, Alegretti JR, Baracat EC, Olive D and Serafini PC (1998) High implantation and pregnancy rates with transfer of human blastocysts developed in preimplantation stage one and blastocyst media Fertility and Sterility $70659-663$

Artley JK and Braude PR (1993) Biochemistry of the preimplantation embryo Assisted Reproduction Reviews 3 13-18

Artley JK, Braude PR and Johnson MH (1992) Gene activity and cleavage arrest in human pre-embryos Human Reproduction 7 1014-1021

Ben-Chetrit A, Jurisicova A and Casper RF (1996) Coculture with ovarian cancer cell enhances human blastocyst formation in vitro. Fertility and Sterility $65664-666$

Bolton VN, Oades PJ and Johnson MH (1984) The relationship between cleavage, DNA replication and gene expression in the mouse 2-cell embryo Journal of Embryology and Experimental Morphology 79 139-163

Bolton VN, Hawes SM, Taylor CT and Parsons JH (1989) Development of spare human preimplantation embryos in vitro: an analysis of the correlations among gross morphology, cleavage rates, and development to the blastocyst Journal of In Vitro Fertilisation and Embryo Transfer 6 30-35

Braude P, Bolton V and Moore S (1988) Human gene expression first occurs between the four- and eight-cell stages of preimplantation development Nature $332459-461$

Braude PR, Pickering SJ, Winston NJ, Artley JK and Johnson MH (1990) The development of the human preimplantation embryo. In Proceedings III Renier de Graaf Symposium, From Ovulation to Implantation p. 251. Elsevier, Oxford

Capmany G and Bolton VN (1993) Polypeptide profiles of human oocytes and preimplantation embryos Human Reproduction 8 1901-1905

Crosby IM, Gandolfi F and Moor RM (1988) Control of protein synthesis during early cleavage of sheep embryos Journal of Reproduction and Fertility $82769-775$

Davis D (1985) Culture and storage of pig embryos Journal of Reproduction and Fertility Supplement 38 115-124

Desai N, Kinzer D, Loeb A and Goldfarb J (1997) Use of synthetic serum substitute and alpha-minimum essential medium for the extended culture of human embryos to the blastocyst stage Human Reproduction 12 328-335

Dionne P, Duchesne C and Sullivan R (1989) Qualitative changes in protein synthesis associated with polyspermic fertilisation of human eggs Molecular Reproduction and Development $1249-253$

Flach G, Johnson M, Braude P, Taylor R and Bolton V (1982) The transition from embryonic to maternal control in the 2-cell mouse embryo $E M B O$ Journal 1 681-686

Frei R, Schultz G and Church R (1989) Qualitative and quantitative changes in protein synthesis occur at the 8-16-cell stage of embryogenesis in the cow Journal of Reproduction and Fertility 86 637-641

Gardner DK and Lane $\mathbf{M}$ (1998) Culture of viable human blastocysts in defined sequential serum-free media Human Reproduction 13 Supplement 3 148-160

Gardner DK, Vella P, Lane M, Wagley L, Schlenker T and Schoolcraft WB (1998) Culture and transfer of human blastocysts increases implantation rates and reduces the need for multiple embryo transfers Fertility and Sterility $6984-88$

Gifford DJ, Fleetham JA, Mahadevan MM, Taylor PJ and Schultz GA (1987) Protein synthesis in mature human oocytes Gamete Research 18 97-107

Hardy K, Hooper MAK, Handyside AH, Rutherford AJ, Winston RML and Leese HJ (1989) Non-invasive measurement of glucose and pyruvate uptake by individual human oocytes and preimplantation embryos Human Reproduction 4 188-191

Howlett SK (1986) The effect of inhibiting DNA replication in the one-cell mouse embryo Roux's Archives of Developmental Biology $195499-505$

Howlett SK and Bolton VN (1985) Sequence and regulation of morphological and molecular events during the first cell cycle of mouse embryogenesis Journal of Embryology and Experimental Morphology 87 175-206

Johnson MH and Nasr-Esfahani MH (1994) Radical solutions and cultural problems: could free oxygen radicals be responsible for the impaired development of preimplantation mammalian embryos in vitro? Bioessays 16 31-38

Jones GM, Trounson AO, Gardner DK, Kausche A, Lolatgis N and Wood C (1998a) Evolution of a culture protocol for successful blastocyst development and pregnancy Human Reproduction 13 169-177

Jones GM, Trounson AO, Lolatgis N and Wood C (1998b) Factors affecting the success of human blastocyst development and pregnancy following in vitro fertilisation and embryo transfer Fertility and Sterility 70 1022-1029

Laemmli UK (1970) Cleavage of structural proteins during the assembly of the head of bacteriophage T4 Nature 227 680-685

Levy R, Benchahib M, Cordonier H, Souchier C and Guerin JF (1998) Laser scanning confocal imaging of abnormal or arrested human preimplantation embryos Journal of Assisted Reproduction and Genetics 15 485-495

Martin KL, Barlow DH and Sargent IL (1998) Heparin-binding epidermal growth factor significantly improves human blastocyst development and hatching in serum-free medium Human Reproduction 13 1645-1652

Menezo YJ, Sakkas D and Janny L (1995) Co-culture of the early human embryo: factors affecting human blastocyst formation in vitro. Microscopy Research Technology 32 50-56

Muggleton-Harris AL, Glazier AM, Pickering S and Wall M (1995) Genetic diagnosis using polymerase chain reaction and fluorescent in situ hybridization analysis of biopsied cells from both the cleavage and blastocyst stages of individual cultured human preimplantation embryos Human Reproduction 10 183-192

Munné S, Grifo J, Cohen J and Weier H-UG (1994) Chromosome 
abnormalities in human arrested preimplantation embryos: a multipleprobe FISH study American journal of Human Genetics 55 150-159

Munné S, Alikani M, Tomkin G, Grifo J and Cohen J (1995) Embryo morphology, developmental rates, and maternal age are correlated with chromosome abnormalities Ferility and Sterility 64 382-391

Petzoldt U, Hoppe PC and Illmensee K (1980) Protein synthesis in enucleated fertilised and unfertilised mouse eggs Wilhelm Roux Archives of Developmental Biology 189 215-219

Plachot M, Junca A-M, Mandelbaum J, Cohen J and Salat-Baroux J (1988) Les échecs du développement embryonnaire Reproduction Nutrition et Développement 28 1781-1790

Plachot M, Mandelbaum J, Junca A-M, de Grouchy J, Salat-Baroux J and Cohen J (1989) Cytogenetic analysis and developmental capacity of normal and abnormal embryos after IVF Human Reproduction Supplement 499-103

Quinn P and Margalit R (1996) Beneficial effects of coculture with cumulus cells on blastocyst formation in a prospective trial with supernumerary embryos Journal of Assisted Reproduction and Genetics 13 9-14

Saito H, Hirayama T, Koike K, Saito T, Hohara M and Hiroi M (1994) Cumulus mass maintains embryo quality Fertility and Sterility 62 555-558

Sakkas D, Batt P and Cameron A (1989) Development of preimplantation goat (Capra hircus) embryos in vivo and in vitro. Journat of Reproduction and Fertility 87 359-365

Sathananthan AH (1994) Functional competence of abnormal spermatozoa. In Bailliere's Clinical Obstetrics and Gynaecology: Micromanipulation Techniques p. 141 Ed. S Fishel. Bailliere Tindall, London

Schultz GA, Gifford DJ, Mahadevan MM, Fleetham JA and Taylor PJ (1988) Protein synthetic patterns in immature and mature human oocytes Annals of the New York Academy of Sciences 541 237-247

Seshagiri PB, Bavister BD, Williamson JL and Aiken JM (1990) Qualitative comparison of protein production at different stages of hamster preimplantation embryo development Cellular Differentiation and Development 31 161-168
Shoukir Y, Chardonnens D, Campana A, Bischof P and Sakkas D (1998a) The rate of development and time of transfer play different roles in influencing the viability of human blastocysts Human Reproduction 13 676-681

Shoukir Y, Chardonnens D, Campana A, Bischof P and Sakkas D (1998b) Blastocyst development from supernumerary embryos after ICSI: a paternal influence? Human Reproduction 13 1632-1637

Telford N, Watson A and Schultz G (1990) Transition from maternal to embryonic control in early mammalian development: a comparison of several species Molecular Reproduction and Development 26 90-100

Turner K and Lenton EA (1996) The influence of Vero cell culture on human embryo development and chorionic gonadotrophin production in vitro. Human Reproduction 11 1966-1974

Van Blerkom J (1998) Epigenetic influences on oocyte developmental competence: perifollicular vascularity and intrafollicular oxygen journal of Assisted Reproduction and Genetics 15 226-231

Van Blerkom J, Davis PW and Lee J (1995) ATP content of human oocytes and developmental potential and outcome after in vitro fertilisation and embryo transfer Human Reproduction 10 415-424

Warner CM, Cao W, Exley GE, McElhinny AS, Alikani M, Cohen J, Scott RT and Brenner CA (1998) Genetic regulation of egg and embryo survival Human Reproduction 13 Supplement 3 178-196

Waterstone JJ and Parsons JH (1992) A prospective study to investigate the value of flushing follicles during transvaginal ultrasound-directed follicle aspiration Fertility and Sterility 57 221-223

Watson AJ, Hogan A, Hahnel A and Schultz GA (1993) Activation of the embryonic genome: comparisons between mouse and bovine development. In Preimplantation Embryo Development p. 115 Ed. BD Bavister. SpringerVerlag, New York

Wiemer KE, Dale B, Hu Y, Steuerwald N, Maxson WS and Hoffman DI (1995) Blastocyst development in co-culture: development and morphological aspects Human Reproduction 10 3226-3232 